\title{
Presupposition Triggers and Presumptive Interpretation
}

\author{
Fabrizio Macagno
}

\begin{abstract}
Pragmatic presuppositions are analyzed considering their relation with the notion of commitment, namely the dialogical acceptance of a proposition by an interlocutor. The attribution of commitments carried out by means of pragmatic presupposition is shown to depend on the reasonableness of the underlying presumptive reasoning, ultimately grounded on hierarchies of presumptions. On this perspective, the ordinary interpretation of pragmatic presuppositions as the "taking for granted" of propositions signaled by semantic or syntactic triggers becomes only the presumptive, prototypical interpretation of a complex linguistic and pragmatic phenomenon. It will be shown how the prototypical interpretation is subject to default in cases of conflicts of presumptions, which lead to reconstructing the speaker's meaning non-presumptively at a pragmatic, semantic, or syntactic level. The phenomena of presupposition cancellation and neutralization can be explained in terms of presumptive and non-presumptive articulation and interpretation of an utterance, through which the speaker can impose, correct, or refuse implicit commitments.
\end{abstract}

\section{Introduction}

Strawson, in his paper On referring, made a crucial distinction between a sentence (or an expression), the use of a sentence (or of an expression), and the utterance thereof (Strawson 1950, 325). While sentences (such as "The king of France is wise") can be said to have meaning, only the uses of a sentence within a context to talk about a specific referent can be said to be true or false ("The king of France is wise" used to refer to Luis XIV). Moreover, a sentence can be used in the same way in different utterances ("The king of France is wise" uttered by two distinct

\footnotetext{
F. Macagno ( $\bowtie)$

Instituto de Filosofia da Nova (IFILNOVA), Faculdade de Ciências Sociais e Humanas,

Universidade Nova de Lisboa, Lisboa, Portugal

e-mail: fabrizio.macagno@fcsh.unl.pt
} 
speakers in the seventeenth century). Strawson maintains that in case the king of France does not exist, the "question whether the statement istrue or false doesn't arise" (Strawson 1964a, 112). He points out that questions concerning the king of France ("Is the king of France wise?") can be only answered by rejecting the question. Similarly, statements about unidentifiable referents or inexistent entities ("This is a fine red one," uttered indicating the speaker's cupped and empty hands) can be replied only by rejecting the assertion ("But there is nothing in your hands") (Strawson 1950, 333). On Strawson's view, the fact that a sentence is uttered without using it to refer to an existing entity (reference failure), makes its use spurious, as it cannot be true or false.

Strawson, in his analysis of existential presuppositions, underscored a crucial aspect thereof, namely the dialogical nature of presupposition. On his view, the act of referring to an entity is a requirement (namely a presupposition) of the act of asserting, namely using a sentence to perform a specific speech act (Reimer and Bezuidenhout 2004, 308). However, interpreting Austin, Strawson claims that the felicity of the use of a sentence depends on the recognition of the intention to produce a specific response (Strawson 1964b, 449). For this reason, according to him the aim (if not the achievement) of a speech act is the interlocutor's understanding of the intention of eliciting a specific response (for example, asserting is aimed at informing the interlocutor of a specific propositional content $p$, so that he can behave accordingly - namely continuing the dialogue or act based on $p$ ). If we develop this idea, we can analyze the problem with presupposition failures (namely referential failures in Strawson's cases) in terms of the possibility of eliciting the intended response. The use of "The king of France is wise" in a context in which the interlocutor maintains that there is no king of France would result in a "spurious use" of the sentence, as it fails to inform the hearer of an fact that he can possibly consider to be acceptable or not (and act accordingly).

Strawson's idea of investigating (existential) presuppositions as properties of utterances (Huang 2014), which we can regard as conditions for their felicitous use, can be used for analyzing the relationship between other relationships between presupposition triggers and pragmatic presuppositions. ${ }^{1}$ His approach can be interpreted in a dialogical perspective in terms of dialogical commitments that the speaker can attribute to the hearer based on presumptions. On this view, presuppositions can be regarded as propositions that the speaker treats as taken for granted, namely propositions that can be presumed as implicit commitments of the hearer (Geurts 1999, 4; Macagno 2018). This account is grounded on two basic ideas: (1) instead of analyzing presuppositions as true or false propositions, they can be described as commitments, which are attributed to the hearer and that the hearer can accept, accept provisionally, or reject (by rejecting the interlocutor's

\footnotetext{
${ }^{1}$ Clearly, Strawson's later definition of presupposition (Strawson 1954) conflicts with the account of pragmatic presupposition (Reimer and Bezuidenhout 2004, 308; Stalnaker 1973, 1974, 2002). The point we want to make is that Strawson's original idea of connecting presupposition with utterances can be developed in dialogical terms.
} 
utterance) (Von Fintel 2004); and (2) the possibility of presupposing consists in a type of reasoning based on presumptions of what the hearer is committed to or can accept to be committed to.

\section{Presuppositions and Commitments}

The relationship between presupposition and the use of a sentence in an utterance is commonly described in terms of pragmatic presupposition. Stalnaker introduced the idea that to presuppose (pragmatically) a proposition is "to take its truth for granted, and to assume that others involved in the context do the same" (Stalnaker 1974, 472). A proposition $p$ is presupposed when it is taken for granted by a person in performing a speech act (whether an assertion or a different speech act), whose felicity, or conversational acceptability depends on the interlocutor's acceptance of p (Stalnaker 1974, 2002; Allan 2013). This approach can be described as based on two principles: (1) the presupposition of $p$ is a condition of the appropriateness of the use of a sentence; and (2) presupposing consists in taking its truth for granted, based on the belief that $p$ is a part of the common ground (namely all the conversational participants accept that $p$ and it is common belief that everyone accepts that $p-$ namely acts as though $p$ were true) (Reimer and Bezuidenhout 2004, 308). However, since presupposition is defined in dialectical terms, also the idea of truth needs to be analyzed dialectically without taking into account its epistemic dimension.

A proposition taken to be "true for" someone, or "accepted as true," can be considered dialogically to be a commitment of someone, namely a proposition that using Stalnaker's terminology - is accepted. As Stalnaker puts it (Stalnaker 1984):

To accept a proposition is to treat it as a true proposition in one way or another-to ignore, for the moment at least, the possibility that it is false. [...] As a rough criterion, one may say that a propositional attitude concept is an acceptance concept if the attitude is said to be correct whenever the proposition is true. Belief is an acceptance concept because a correct belief is a true belief.

An accepted proposition in a dialogical context is a commitment, as it results in dialogical constraints. A commitment is an accepted proposition that, however, is defined in terms of its possibility of being retracted, denied, or questioned, and not directly in epistemological terms as a proposition treated as a possibly true or false. The propositional attitude is thus translated as a dialogical attitude (Macagno 2018). In this sense, a commitment is not necessarily a belief; rather, one accepts a statement when one asserts it and, in many contexts, when someone else asserts it to you and you do not object (Mackenzie and Staines 1999, 17; Hamblin 1970, 264; Geurts 2017).

A commitment is one's position at a stage in a dialogue, a proposition resulting from the acceptance (or the presumption of the acceptance, in case of implicit commitments, see Walton and Krabbe 1995, 186) of a statement by a participant to a dialogue, which thus is included in the speaker's (or hearer's) commitment store. 
Commitments are public, as they represent what the participant to a dialogue is held responsible for (i.e. what he is held to support it in case it is challenged, which he cannot contradict without retracting it) (see for this notion Walton and Krabbe 1995; Hamblin 1970; Soames 2002; Gazdar 1981). They can be distinguished in light-side commitments, namely the ones that are the result of an assertion in a dialogue, and dark-side commitments, namely commitments resulting from the common ground, a set of propositions that the interlocutors consider to be shared and not subject to further discussion (Walton 1985, 1987; Walton and Krabbe 1995). While light-side commitments can be challenged directly (by questioning or refusing the interlocutor's stated content, or simply by not accepting it explicitly), dark side commitments cannot, as they are presented as propositions upon which the parties to a dialogue to have already agreed (Walton and Krabbe 1995, 182). Stalnaker seems to distinguish this class of accepted propositions by referring to a "more passive" acceptance of propositions whose falsity never occurred to the speaker (see Stalnaker 1984, 80). In this case, a meta-dialogue or meta-dialogical move is needed for retracting such commitments, in which the interlocutor needs to show why he cannot accept the dark-side commitment.

Commitments are only indirectly related to beliefs. A speaker can be committed to a proposition without believing that it is true; so he can also commit someone else (presenting a proposition as commonly accepted) even though he cannot know whether it is actually believed or not (Beyssade and Marandin 2009). ${ }^{2}$ Moreover, commitments can be demanded, attributed, or rejected, and the speaker can distinguish between assertions aimed at calling for speaker's commitments from the ones aimed at committing the speaker only (Beyssade and Marandin 2006). Commitments are purely dialogical obligations, which can be justified in terms of beliefs. However, the dialogical and the epistemological (or psychological) level cannot be confused. By distinguishing commitments from acceptance and beliefs it is possible to analyze real or fictional dialogues (such as dialectical challenges, the obligation games, etc.) and interactions without resorting to what the interlocutors think or believe, but relying only on what they are responsible for.

The idea of commitment can lead to an interpretation of presupposition not in terms of "common ground" but in terms of expectations, namely argumentative reasoning. This point was clearly made by Atlas $(2005,144)$ :

This store of noncontroversial information is accessible for use in a conversation; it need not be explicitly a part of the common ground, or part of mutual knowledge, for purposes of a particular conversation. But what is noncontroversial on the occasion of an utterance need not have been stored at all. A speaker's expectation that an addressee will charitably take the speaker's word that a singular term ' $t$ ' is nonvacuous is not the same as a speaker and addressee's expectations that they have in common the thought't exists'. What they linguistically have in common is not a background belief; it is a language-based practice or convention of interpretation that allows certain bits of language, such as singular terms, charitably to have a taken-for-granted semantic evaluation in the course of making and

\footnotetext{
${ }^{2}$ According to Gazdar, however, commitments and beliefs are not distinguished, as commitments concern contents presented as a true belief (Beyssade and Marandin 2009).
} 
understanding assertions, but only if the singular terms are topic noun phrases in the assertions or if the singular terms purport to designate what the statement is "about."

The idea of non-controversiality (instead of common ground) as a condition for presupposing changes the perspective on what presupposition is, and what the act of presupposing amounts to. A presupposition becomes the outcome of a reasoning process, which can be reasonable or not and can yield different interpretative conclusions. Two crucial distinctions need to be made at this point. First, as a component of meaning (an implicatum according to Atlas and Levinson) on which the speaker's meaning depends, presupposition needs to be interpreted as a kind of act. Second, as a presumptive conclusion, the presupposed content needs to be compared with the conflicting presumptions, and the result of this comparison needs to be assessed.

\section{Presupposition and Speech Acts}

The idea of commitment depends on the notion of acceptance, as the dialogical attitude is grounded on the propositional one. The prototypical act of accepting a proposition is asserting it, or asserting one's one acceptance to a proposition. Presupposition, however, acts prototypically in a different way. A presupposition does not usually modify (at the level of propositional attitudes) the interlocutors' knowledge of what is held as true - nor (at a dialogical level) what are the commitments at a stage of the dialogue. Presupposition, rather, refers to an accepted proposition and the act of using dark-side commitments to generate new, explicit ones. This type of propositional attitude is a meta-attitude: it does not correspond to acting as a proposition is true or is to be defended or not contradicted; rather, it consists in using, or referring to, an attitude. This type of act on the interlocutors' commitments can be described as a kind of speech act.

From a propositional-attitude point of view (which we can equate to the neustic function, see Recanati (2016), Hare (1970), 20-21), a presupposition consists in treating a proposition as accepted by the speaker and the hearer, namely ascribing a proposition to both parties to a discussion. For this reason, they act as attributions of acceptance on both parties to a discussion, and they do not need to refer to previous acceptance. As Stalnaker noticed, presuppositions are "beliefs ascribed even though the believer has never expressed or consciously thought about them" (Stalnaker 1984). However, this does not amount to the possibility of reasonably presupposing all propositions. Treating a proposition as accepted needs to be based on reasons, namely the speaker needs to have reasons supporting the conclusion that a proposition is accepted or that the interlocutor does not disagree with it.

The neustic treatment of presupposition does not explain how an attitude is ascribed (or rather a proposition is subscribed, using Hare's terminology) in terms of acts. To this purpose, the neustic force can be reinterpreted as commitments, namely as dialogical (instead of only propositional) attitudes. On this view, presuppositions are dialogical attitudes that impose certain limits to the interlocutor's possible 
dialogical moves, and are the result of speech acts that are mentioned and that can be upheld or denied. Both aspects of this treatment of presupposition have been addressed by Ducrot in his linguistic theory.

On Ducrot's perspective, presuppositions constrain the field of the possible moves of the interlocutor within a dialogue game. An assertion ("The king of France is bald") leaves the interlocutor with the possibility of continuing the dialogue concerning a specific topic (the king of France) or terminating the dialogue ("There is no king of France"). In both cases, the interlocutor reacts to a new commitment that had not undertaken before the utterance, namely that he accepts that there is a king of France. Ducrot accounted for this pragmatic effect of presupposition defining it as an implicit speech act (Ducrot 1968, 87):

Comme le joueur d'échecs doit accepter le champ de possibilités que crée pour lui la manœuvre de son adversaire, le participant d'un dialogue doit reprendre à son compte certains au moins des présupposés introduits par les phrases auxquelles il répond.

Ducrot pointed out that a presupposition is the result of a distinct act, aimed at setting the possible moves that can be performed by the interlocutor, that is, the possible dialogical world that determines the boundaries of the linguistic moves (Ducrot 1972a). As Ducrot puts it (Ducrot 1972b, 91):

\footnotetext{
Présupposer un certain contenu, c'est placer l'acceptation de ce contenu comme la condition du dialogue ultérieur. On voit alors pourquoi le choix des présupposés nous apparaît comme un acte de parole particulier (que nous appelons acte de présupposer), acte à valeur juridique et donc illocutoire $[\ldots]$ : en accomplissant, on transforme du même coup les possibilités de parole de l'interlocuteur. [...] Lorsqu'on introduit des présupposés dans un énoncé, on fixe, pour ainsi dire, le prix à payer pour que la conversation puisse continuer
}

While assertion can be counted as a proposal of adding a proposition $p$ to the shared propositions, presupposing can be considered as the act of treating $p p$ as already shared (Atlas 2008; von Fintel 2008). However, a crucial problem arises concerning the nature and the conditions of the act that a speaker performs by presupposing.

\section{Defaultive Interpretations. The Acts of Presupposing}

As Ducrot and other authors mentioned above points out, presupposing consists in a twofold act: (1) taking a proposition $(p p)$ for granted, namely treating it as part of the commitments shared by the speaker and the hearer, and (2) positing it as a condition for the felicity of a speech act. However, these two aspects of pragmatic presupposition need to be distinguished and analyzed in detail. The first act consists in imposing a constraint on the interlocutors' set of shared and accepted propositions. The second act imposes a constraint on the interpretation of the utterance, namely consists in treating $p p$ as a proposition necessary for the default interpretation of the speaker's communicative intention. These two acts are usually prototypically performed, in the sense that the speaker takes for granted what is presumed to be uncontroversial, and uses $p p$ as condition for a 
common interpretation of an utterance (Levinson 2000, 60; 73). However, this is only a prototypical linguistic behavior. The linguistic reality is much more complex. Our default interpretation of an utterance (the utterance-type, see Levinson 2000) depends the prototypical interpretation of linguistic items, the prototypical interpretation of the linguistic intentions associated with their use, and (as we will maintain below) the prototypical articulation of an utterance in terms of attribution of commitments. All these three aspects can be subject to default, resulting in different pragmatic presuppositions (Geurts 1999, 32-33).

Presupposition can contribute to the speaker's meaning by affecting in different way the interlocutor's and the speaker's commitments. In the default condition, presuppositions "reinforce propositions already in the common ground of a conversation"(Atlas 2005, 144), namely bring to the light side implicit commitments held by the interlocutors. This type of act is a kind of reminder (Searle and Vanderveken 2005), namely an act that has as a preparatory condition the fact that the hearer once knew (was committed to) $p$. However, this act is a twofold reminder, as also the speaker is bound to the acceptance of $p$, without having expressed his acceptance previously in the dialogue. For example, we consider the following:

1. Santa Clause will come tonight (the father to his little son)

2. Santa Clause will come tonight (the father to his grown up son, who discovered that Santa does not exist)

Both utterances commit the speaker and the hearer to the same proposition (Santa exists), even though they have different effects. In both cases, the father is reminding the son of his own and his son's commitment. However, in the second case the son needs to correct meta-dialogically the commitment that he does no longer hold. In both cases, the twofold direction applies also to the sincerity condition: the speaker can use his act as a sign of belief in $p$, and as a sign that he believes that the hearer is committed to $p$. In order to investigate deeper the conditions of this act, it is necessary to investigate how and why the speaker can know that the hearer was committed to $p$. To this purpose, it is necessary to take into account the related notions of accommodation and acceptance.

The problem of describing the conditions of the act of reminding is rooted, in the case of presupposition, in the concept of presumption. Since it is impossible to know the interlocutor's knowledge, it is at least possible to presume his commitments from the available information, which can be contextual (propositions not previously challenged), encyclopedic, or resulting from shared knowledge. Such presumptions can provide an explanation of the phenomenon of accommodation, namely the bridging between the speaker's and the hearer's commitment store. Accommodation describes the limits of the reconstruction of presuppositions, namely two crucial conditions: (1) the hearer needs to be able to derive the presupposed information from the co-text (Asher and Lascarides 1998); and (2) the presuppositions need to be acceptable, namely not conflicting with what is accepted (Atlas and Levinson 1981; Atlas 2005, chap. 4), or with the propositions that the hearer holds to be true or acceptable. These criteria a sufficient for making the speech act of reminding possible (the commitment needs to be identifiable; the commitment needs to be 
potentially an actual commitment). However, they are not enough for making this act reasonable. In order to be reasonable, a reminder needs to be grounded on reasons. We will analyze this requirement after describing in detail the two aforementioned essential conditions.

As mentioned above, the first and most basic condition consists in the possibility of accessing (identifying) the presupposed information. It is impossible to remind the hearer of a commitment unless he can retrieve it. The presupposed content needs to be retrievable by the interlocutor, namely the latter needs to be able to reconstruct the content taken for granted and connect it with its knowledge or the context (Asher and Lascarides 1998, 277; Gazdar 1979; Hobbs 1979). In this sense, the hearer needs to be able to accommodate the presupposition (Simons 2003; von Fintel 2008; Atlas 2008; Lewis 1979). The second condition consists in the acceptability of the presupposed information. The hearer can be reminded of a previous commitment only if such an information does not openly conflict with his commitments (Atlas and Levinson 1981, 40-41), or at least the ones that he holds more steadily. It is possible to remind the hearer of a commitment only because it has been already accepted by him (it is part of the context), namely (as a weaker criterion) the hearer is not known to be committed to conflicting propositions (Soames 1982, 486). This criterion can explain the absurdity of utterances such as the following (Stalnaker 1998):

3. I have to pick up my Martian friend.

4. The king of France is bald.

In both cases, the hearer cannot be known not to hold conflicting commitments. If we represent this condition in epistemic terms instead of knowledge, we can express it as a twofold presumption: the speaker needs to have grounds for presuming that the hearer does not to hold contrary commitments (possibility of acceptance); and the speaker needs to have grounds for presuming that the hearer has accepted the presupposed proposition (reasonableness of acceptance). This distinction can explain problematic cases of presuppositions, such as case 2 above or 5 below:

2. Santa Clause will come tonight (the father to his grown up son, who has previously informed that Santa does not exist)

5. My boyfriend and I are moving to Las Vegas (the daughter to her father, to whom she never said to have a boyfriend)

In both cases, the speaker cannot presume that the hearer accepted the presupposed proposition. However, while in case 2 the father cannot presume that the son may possibly be committed to the existence of Santa Clause, as he knows the contrary, this possibility is not excluded in 5 . The problem with 5 is that the speaker cannot presume that the father is committed to the fact that she has a boyfriend, since she never informed him thereof. In this case, the proposition cannot be said to be controversial (the father indeed may expect that his daughter has a boyfriend); however, it is not presumable to be a commitment of the father.

To summarize, the analysis of the speaker's dimension in the prototypical act performed in presupposing (reminding the hearer of a past commitment) needs 
to take into account the reasons on which the presupposed propositions can be considered as acceptable. As seen above, it is possible distinguish between three different cases in which the accommodation fails, due to distinct factors:

(i) Identification: the presupposition cannot be identified or reconstructed (the hearer does not know or cannot be presumed to be able to identify the presupposition);

(ii) Possibility of acceptance: the presupposition can be identified or reconstructed but it cannot be accepted (the hearer is known not to accept the presupposed content);

(iii) Reasonableness: the presupposition can be identified or reconstructed but the accommodation reasoning cannot be accepted (the hearer cannot be presumed to know or accept the presupposed content).

These three cases represent three instances of a basic condition of the act of reminding the hearer of a commitment, namely the reasonableness of the speaker's presumptive reasoning underlying his presuppositions. It is possible to represent this act and the conditions thereof as follows (Macagno and Walton 2014, 179; Macagno 2015):

\begin{tabular}{l|l}
\hline Essential condition: & $\begin{array}{l}\text { Speaker }(S) \text { considers the presupposed proposition }(p p) \text { as an } \\
\text { implicit (previous) commitment of both the Speaker and the Hearer. }\end{array}$ \\
\hline Propositional condition: & $\begin{array}{l}p p \text { is a proposition/fact/value/role that can be identified or } \\
\text { reconstructed by } H .\end{array}$ \\
\hline Preparatory condition: & $S$ can presume that $H$ has accepted (is committed to) $p p$. \\
\hline Sincerity condition: & $S$ believes that $p p ; S$ believes that $H$ has accepted $p p$. \\
\hline
\end{tabular}

The possibility of identifying the presupposition is set as a propositional condition $(H$ needs to be able to draw $p p$ from the linguistic and pragmatic elements provided). The acceptanceand the reasonablenessof the presupposition is expressed by the preparatory and the sincerity conditions. In particular, the preparatory condition, expressed in terms of presumption, is aimed at bridging the gap between the speaker's and hearer's mind from an epistemic and argumentative perspective (Macagno and Walton 2014, chap. 5; Macagno 2015). This idea is the development of Strawson's presumption of knowledge (Strawson 1971, 58-59; Kempson 1975, 166-67) and the principle of Relativity developed by Atlas and Levinson (Atlas and Levinson 1981, 40):

1. Do not say what you believe to be highly noncontroversial - that is, to be entailed bythe presumptions of the common ground.

2. Take what you hear to be lowly noncontroversial-that is, consistent with thepresumptionsof the common ground.

A crucial dimension of the act of presupposition consists in the conclusion of presumptive reasoning. In this sense, in addition to be possible, a presupposition needs to be regarded also as reasonable. The crucial issue at this point is to determine 
how to assess a reasonable presumption, and what happens when presumptions conflict with each other.

\section{Presuppositions as Presumptive Reasoning}

As seen above, presupposing consists in taking a proposition for granted, inasmuch as it is already accepted, known, or shared. However, this pragmatic phenomenon lies on a gap of knowledge, as the speaker cannot know what the interlocutor accepts or knows. In order for the act of presupposing to be reasonable or acceptable, the condition that the presupposed proposition needs to be accepted or known is unrealistic. A realistic requirement can be stipulated in terms of defeasible reasoning (Walton et al. 2008), namely a provisional conclusion concerning the hearer's acceptance or knowledge of the presupposed contents (Simons 2013). This type of reasoning is called presumptive reasoning (Walton 1995), a type of inference that can be described as follows (Rescher 2006, 33):

Premise 1: $P$ (the proposition representing the presumption) obtains whenever the condition $C$ obtains unless and until the standard default proviso $D$ (to the effect that countervailing evidence is at hand) obtains (Rule).

Premise 2: Condition $C$ obtains (Fact).

Premise 3: Proviso $D$ does not obtain (Exception).

Conclusion: $P$ obtains.

The first premise expresses the rational principle supporting the conclusion, which is drawn from general experience or probability and is subject to specific defeasibility conditions. This type of reasoning can be used to describe the nature of the presupposed propositions, namely the possible reasonable ground on which they stand. The acceptability of a presupposition, as mentioned above, can be based on different types of presumptive rules, depending on their level of genericity or defeasibility (Rescher 2006, 6). We can identify four broad categories:

1. linguistic presumptions (commonly accepted meaning of lexical items; definitions... );

2. encyclopedic presumptions (information that considered to be shared because it concerns facts, events, and descriptions of the world as socially conceived);

3. evaluative presumptions (concerning information concerning the values and preferences of the interlocutor); and

4. pragmatic presumptions (including expectations about the interpretation of speech acts and the presumptions concerning the speaker's intentions).

The levels of presumptions can be represented as follows (Fig. 1): 


\begin{tabular}{|c|c|}
\hline & $\begin{array}{l}\text { Levels of } \\
\text { presumptions }\end{array}$ \\
\hline 0. Pragmatic & $\begin{array}{l}\text { Sentence - purpose of the sentence } \\
\text { (ex. Assertive sentences are usually used to } \\
\text { inform the hearer). }\end{array}$ \\
\hline 1. Linguistic & $\begin{array}{c}\text { Definitions, syntactic structures } \\
\text { (ex. 'Man' is usually used to mean a 'rational } \\
\text { animal'). }\end{array}$ \\
\hline 2. Factual, encyclopedic & $\begin{array}{l}\text { Customs, habits and stereotypes } \\
\text { (ex. France is not a monarchy now). }\end{array}$ \\
\hline 3. Values and preferences & $\begin{array}{l}\text { The interlocutor's interests/values... } \\
\text { (ex. My interlocutors are against abortion). }\end{array}$ \\
\hline
\end{tabular}

Fig. 1 Levels of presumptions

The two criteria mentioned above, i.e. analysis of presuppositions in terms of conclusions of presumptive reasoning and the ordering of presumptions depending on their defeasibility conditions (presumptions that are more generic are more likely to be defeated by contextual information) allow investigating presupposition failures and the process of accommodation in terms of conflicts of presumptions. For example, we analyze the aforementioned sentence "The king of France is wise" uttered during the French Republic:

\begin{tabular}{l|l}
\hline Premise 1: & $\begin{array}{l}\text { P(the Hearer accepts that there is king of France) obtains whenever the } \\
\text { condition } C \text { (the Hearer lives in France) obtains unless and until the standard } \\
\text { default proviso D (the Hearer is a child; is ignorant ... ) obtains. ( } \underline{\text { Rule })}\end{array}$ \\
\hline Premise 2: & $\begin{array}{l}\text { Condition C (the Hearer aaccepts that there is king of France) CANNOT } \\
\text { obtain (conflicting presumption: the Hearer holds that France is a Republic as } \\
\text { people are presumed to accept it during the French Republic). (Fact) }\end{array}$ \\
\hline Premise 3: & Proviso D (the Hearer is a child/ignorant) does not obtain. (Exception) \\
\hline Conclusion: & P(the Hearer accepts that there is king of France) OBTAINS. \\
\hline
\end{tabular}

In this case, we notice that the presupposition fails to be accepted because the presumptive reasoning underlying it is contradicted by contrary evidence resulting from the context (knowledge of the interlocutor or falsity of the encyclopedic presumption). In case the speaker is presupposing that there is the king of France, we notice that there is a conflict between presumptions of two different levels. An encyclopedic presumption (Level 2), i.e. that the interlocutor knows that there is a king of France, is contradicted by another encyclopedic one (France is a Republic), supported by further encyclopedic presumptions (people usually know the political situation of France). This conflict makes the act of reminding of a 
presupposition infelicitous. This infelicity can lead to other non-presumptive (nondefault) interpretations of the speaker's meaning.

\section{Pragmatic Defaults: Non-prototypical Presuppositional Acts}

As pointed out above, the act of reminding is grounded on presumptions, and more precisely the presumption that the hearer is committed to $p p$. When this presumption fails, due to the fact that a stronger presumption arises, the presumptive interpretation of the act is subject to default and the speech act needs to be interpreted differently. As Atlas maintains (Atlas 2005, 144), presuppositions can be used for performing various types of acts different in effect:

The speaker's implicata that constitute the "presuppositions" of assertions can reinforce propositions already in the common ground of a conversation, or they can introduce propositions into the common ground, or they can be recognized and then dismissed, never even entering the common ground of a conversation, because they belong to a separate store of information that we characterize as noncontroversial.

In particular, presupposition consists in subordinating the felicity of a speech act to the existence of a commitment in both the speaker's and the hearer's commitment store. However, this can be the result of different acts. For example, by means of a presupposition the speaker can bring to the light side a commitment of the hearer that the latter does not want to be known. In this sense, the presupposition is used to bring forcefully a dark-side commitment to the light-side. For example we consider the following (see Capone 2005):

6. $<$ A friend to another who does not want that his legal problems become public $>$ Tell us what happened with your theft charge. Did you manage to get away with it?

In this case, the presupposition is used for bringing to the light side a proposition that the hearer is presumed to be committed to (he is presumed to be committed to events that happened to him). However, this act is not a pure reminder; the hearer is in fact presumed not to intend to be explicitly committed to this fact. The presupposition in this case is more a directive than a mere reminder, requesting explicit commitment (and accountability).

Other acts can be performed by presupposing. We consider the following cases, together with example 5 above:

5. My boyfriend and I are moving to Las Vegas (the daughter to her father, to whom she never said to have a boyfriend)

7. The King of France is magnificent (uttered by an enemy of Napoleon to a supporter of him during the French Republic) (Ducrot 1966, 42)

8. The King of France is wise, and lives in a golden castle (Strawson 1950, 331)

In 5, the hearer is presumed not to know at all the existence of the speaker's boyfriend (Grice 1989, 274). On the contrary, in some contexts the father's 
knowledge thereof would even surprise the speaker. This type of presupposition cannot be a reminder; on the contrary, it is cannot be obvious to both interlocutors that the hearer can be committed (know) $p p$. The speaker, in uttering 5, intends to insert $p p$ into the father's commitment store in addition to $p$. However, the two acts are different: the father is informed of $p p$ without the speaker taking responsibility for the assertion. While in case of assertion the speaker $S$ needs to have evidence (reasons etc.) for the truth of $p$ (Searle 1969, 66) - namely he has the burden of defending $p$ if requested -, this preparatory condition does not characterize this act of presupposing. The speaker informs the hearer of $p p$ (fulfilling all the conditions for such an act) but evades the burden of making an assertion (not commitment herself to the communicative intention, namely informing the hearer of $p p$ ).

A similar analysis applies to 7 . However, in this case the speaker is presuming not only the hearer's lack of previous acceptance (reasonableness) of $p p$., but also the impossibility of his acceptance of the presupposition (acceptability). This utterance introduces into the hearer's commitment store the proposition that there is a king of France, despite the shared presumption that France is a republic. The utterance, far from being nonsensical or infelicitous, results in the hearer's burden of challenging the presupposition, which will be considered as shared if the dialogue moves on (Macagno and Damele 2013).

The presupposition of 8 has a different effect, namely inserting into the interlocutors' commitment store a proposition that could not be possibly shared before. The speaker, with his utterance, is creating a new commitment and attributing it to both the speaker and the hearer. This act can be a kind of implicit performative, as it cannot be refuted, (it makes little sense to say "But the king does not exist") and depends on the acceptance of the speaker's role (the one in charge of imposing new commitments, in this case a fantastic one, see Recanati 2000, 167-168). A similar linguistic behavior can be observed in normative texts, where an institution or a right ("... the right of the people to keep and bear Arms shall not be infringed"), regardless of being previously introduced, is instituted by presupposing it.

The acts of presupposition examined so far concern assertive utterances. However, presupposition can be used for other types of acts in other types of utterances. A clear example is provided by loaded questions ("Have you stopped beating your spouse?"), namely questions presupposing a proposition that has not been previously accepted by the interlocutor, and which cannot be even presumed to be shared. As Hintikka claimed (Hintikka 2004, 269), "as all aggressive prosecutors (and some precocious children) know, asking a question without having established its presupposition may be a way of making one's opponent admit the presupposition." The presupposition is inserted in the interlocutor's commitment store without him agreeing on it, by his simple acceptance of the speech act (answering it) or failure to object thereto. The hearer has the burden of disproving a commitment, providing a rejection to it. In this sense, the speaker imposes a commitment. We consider the following excerpt from the Trial of Slobodan Milosevic ${ }^{3}$ (page 35496), in which the Prosecution asked a question with an un-shareable presupposition:

\footnotetext{
${ }^{3}$ http://www.icty.org/x/cases/slobodan_milosevic/trans/en/050124IT.htm (Accessed on 21 January 2017).
} 


\section{Case 1}

Prosecution. How was the establishment of the Red Berets in May 1991 justified constitutionally? A paramilitary organization established in May of 1991.

THE ACCUSED: [Interpretation] Mr. Robinson.

JUDGE ROBINSON: Mr. Milosevic.

THE ACCUSED: [Interpretation] I think this is an improper questionbecause it contains an untruthful claim. There were no Red Berets in May of 1991. Even I wouldn't know about that let alone Professor Markovic. What Red Berets? Who? Where? In May of 1991. It's not true.

In this excerpt, the Prosecution asked a question presupposing information to which the Defendant cannot be presumed to be committed (even if it were true, the defendant had not admitted it before). However, the question imposes a burden of disproof onto him. The Defendant has to reject the question (a meta-dialogical move) and provide reasons ("There were no Red Berets, I did not know about that"). In case of any other dialogical answers, he would have been committed to it. This act imposes a commitment, which the hearer has to deny and delete from his commitment store.

Presuppositions can be used to perform directive acts such as imposing or requesting the performance of a specific act (Capone 2005). For example, we consider the following (Macagno and Capone 2016b):

\section{9. <On a sign posted in a restaurant $>$ Thank you for not smoking.}

This utterance, posted on a restaurant, presupposes that the hearer is committed to either a decision (refraining from smoking in the future) or a fact (he has not smoked). However, the hearer cannot be presumed to hold such commitments, as in fact he has not had the possibility of smoking (he has just entered the restaurant) or choosing whether to smoke or not. For this reason, the presupposition cannot be a reminder, but rather a directive: it introduces a commitment to a specific action (the hearer is committed to "not smoking") without his previous acceptance. In this sense, it is a kind of order in which the speaker does not take on the responsibility of imposing onto the hearer a specific course of action ("Do not smoke, please").

From a pragmatic point of view, presuppositions can be used for performing different types of acts. All such acts have in common a specific feature, namely the speaker's failure to take on the responsibility for a modification of the interlocutor's commitment store. In case of presuppositions used for reminding, the commitment store of the interlocutors is not altered in the prototypical cases. However, in some cases the speaker can use presuppositions to bring a dark-side commitment to the light side against the presumed interlocutor's will (example 6). In other cases, it can be used to inform the hearer (example 5), challenge a shared viewpoint (example 7), set out new commitments (example 8), imposing a commitment (case 1), ordering a course of action (example 9). The pragmatic default is only one type of nonprototypical interpretation of presuppositions. Other types of non-defaultive readings can involve linguistic presumptions, both at the semantic and the syntactic level. 


\section{Linguistic Defaults: Non-prototypical Meaning}

When the presupposition is not shared nor shareable, namely when it cannot be the content of speech acts different from reminding, a different type of non-defaultive reconstruction of the speaker's meaning occurs. The hearer can resort to a nondefaultive (or non-presumptive) reconstruction of the meaning of the linguistic elements used in the utterance, such as, for example, lexical items. We consider for examples 7 above and 10 below:

7. The King of France is magnificent <uttered by an enemy of Napoleon to a supporter of him during the French Republic $>$ (Ducrot 1966, 42)

10. Give these flowers to your wife <uttered to a friend who is engaged or has a stable relationship with his girlfriend $>$ (Grice 1989, 270)

Ducrot (1966: 42) noticed how it is possible to imagine the enemies of Cesar or Napoleon during the Roman consulate or the French Republic talking about the magnificence, or the richness or the wisdom of the King. In this case the speakers were presupposing propositions that were simply false at that time, and could not be presumed to be accepted (there was no king of France during the French Republic; there was no king of Rome during the Roman consulate). However, their assertions, far from being void, might have caused them serious troubles for their meaning. The speaker was not forcing the interlocutor to accept a false proposition. On the contrary, he was forcing him to commit himself to a proposition that is the result of a non-presumptive reconstruction of meaning. The expression "the king of France (or of Rome)" is not used to mean "the male monarch whose position is hereditary and who rules for life." Since the existence of this individual conflicts with the stronger presumptions concerning the political situation of France or Rome, the expression could be interpreted as having a different and related meaning, coherent with the stronger encyclopedic presumptions. For this reason, the expression can be interpreted metaphorically to mean the individual who is acting as a king, namely in an authoritarian way. In this sense, the presupposition would commit the hearer (in case of his failure to challenge the utterance) to the qualification of the only referent possible (Napoleon or Caesar) as authoritarian rulers.

The same mechanism of reconstruction of non-presumptive meaning applies to 10 above. The interlocutor cannot be presumed to be committed to have a wife; instead, he can interpret the term (in case the speaker is also presumed that he is not married) to mean "partner." The conflict of presumptions in this case is resolved by adjusting not the "common ground" but rather the presumptive meaning of the presupposition trigger (Atlas and Levinson 1981). Example 2 above can be also interpreted according to this principle of non-presumptive meaning:

2. Santa Clause will come tonight $<$ the father to his grown up son, who discovered that Santa does not exist>

The father presupposes that Santa Clause exists, but both the hearer and the speaker are committed to the fact that he does not exist. Also in this case, there is a conflict 
between the linguistic presumption (Santa exists) and the encyclopedic one (Santa does not exist). The utterance can be interpreted by the child by reconstructing nonpresumptively the meaning of "Santa" as "the person who acts as Santa, namely brings the gifts."

The conflict of linguistic presumptions (presumptive interpretation of triggers or linguistic items) and the encyclopedic ones can lead to a non-defaultive interpretation of the linguistic meaning. When the hearer cannot "accommodate" the presupposition, namely when it is not possible for him to accept a commitment imposed by the interlocutor, he can resort to different interpretive strategies for neutralizing the presupposition. One strategy is the metaphorical interpretation of lexical items; another is the non-presumptive interpretation of polyphonic structure of an utterance.

\section{Syntactic Defaults: Commitments and the Polyphonic Articulation of Utterances}

The analysis of the commitments is the ground of the polyphonic approach to the analysis of utterances. Polyphony (notion introduced by Bakhtin (1981), Voloshinov (1986), and developed by Ducrot (1984)) can be described as the distinction of different voices that are responsible for distinct "speeches" within an utterance (Bakhtin 1986; Bakhtin 1981). On this perspective, an utterance is regarded in dialogical terms as an interconnection between (or incorporation of, according to Voloshinov) distinct points of views, between indirectly reported speeches that only sometimes are explicitly marked as belonging to utterers different from the speaker (Fløttum 2010; Capone 2010, 2016, 2017). Such voices (also called utterers or points of views) are responsible only for some contents (Macagno and Capone 2016a). In this fashion, an utterance becomes a complex structure of indirect reports in which the speaker can agree or disagree with what an utterer says. This articulation of distinct linguistic characters responsible for distinct commitments can explain some crucial cases of presupposition cancellation (Horn 1985; Abbott 2006).

Polyphony hinges on the notion of reported speech, and more precisely of free indirect reports. The fundamental distinction between direct and reported speech consists in its effects on commitments. Indirectly reported speech is not a serious assertion (Clark and Gerrig 1990, 766), namely the speaker does not accepts or commits to the point of view that the reported speech expresses. The speaker merely displays (echoes, mentions, see Recanati 2000, 7) an assertion made by another utterer, using his point of view without taking on the responsibility for it (Recanati 2010). We consider the following example (Recanati 2010):

11. John to Bill: Ok, I am stupid and I don't understand the matter. Why do you ask me for advice then?

John is not asserting that he is stupid and does not understand the matter. He is mimicking, freely indirectly reporting Bill's assertion without committing to it 
(Recanati 2000). The speaker is acting as a "belief ascriber," and his purpose is to show how the world is according to theascribee. The speaker makes a "pretend assertion," not committing to it (Recanati 2000). He shifts the "world" (Recanati 2000) or rather the point of view, namely the commitments that the utterance results in and that presupposes. In this sense, the following utterance (Recanati 2000), made by a father referring to his son's point of view, depicts his son's commitments, or rather shifts his own (dialogical) world to the son's one:

12. Santa Claus will come tonight, even though he does not exist.

The father freely indirectly quotes his son's assertion, and more importantly his son's dialogical world, in which Santa Clause exists and performs specific actions. Moreover, he distinguishes his own view (his own dialogical world in which the utterance is made and evaluated) from the one that is indirectly reported. He expresses a contradiction, or rather a nonsense, which can be solved by reconstructing the polyphonic structure of the utterance and interpreting the first sentence as a non-serious assertion (Recanati 2000), corrected by uttering the concessive clause. In this way, the speaker can distinguish the contents he upholds and the ones which he refuses or does not want to be responsible for (for the analysis of linguistic markers indicating the distance between the speaker and the uttererer, see Nølke 1994a, 86).

Polyphony and the commitments resulting from the various voices of an utterance can provide an instrument for analyzing different cases of presupposition cancellation. In the polyphonic approach to utterances, the distinction between what is stated (posé) and what is presupposed (présupposé) is drawn in terms of discourse responsibilities (in addition to the tests of transformation in the negative and interrogative form). The speaker (locuteur) - the linguistic character responsible for taking charge of the utterance (Ducrot 1984, 179) - is distinguished from the utterers (énonciateurs), namely the "voices" responsible for the contents that have been asserted and presupposed ${ }^{4}$ (Beaver 2010). While the posé is claimed and attributed to speaker, the presupposition is a content asserted and presented as belonging to a "we," a "collective voice" to which the speaker and the interlocutor belong (Ducrot 1969, 1980, 1982, 1984). The speaker thus takes directly the responsibility for what is stated, but only indirectly for what is presupposed. If we interpret this analysis in terms of commitment, we can claim that a stated content is directly inserted in the

\footnotetext{
${ }_{4}{ }_{\text {Je }}$ signalerai enfin une perspective particulièrement prometteuse qui s'ouvre dès qu'on considère le sens comme un représentation de l'énonciation, représentation consistant notamment à y faire entendre la voix de divers énonciateurs s'adressant à divers destinataires et à identifier ces rôles illocutionnaires avec des personnages qui peuvent être, entre autres, ceux de l'énonciation. Il s'agit de la construction, dans le discours, du locuteur et de l'allocutaire. Psycho- et sociolinguistes ont quelquefois noté [...] que l'on peut, en parlant, constituer une image de soi et de la personne à qui l'on parle, image que l'interlocuteur tantôt accepte et tantôt rejette. Un des principaux moyens de cette constitution est. justement la possibilité, inscrite selon nous dans la langue, c'est-à-dire dans la signification des mots et des phrases, de faire s'exprimer différentes voix, en donnant l'instruction de les identifier à des êtres de la réalité -et en spécifiant même certaines contraintes à observer dans cette identification» (Ducrot 1980, 56).
} 
speaker's commitment store, but not in the interlocutor's one, while a presupposed content is placed in both the speaker's and hearer's dark-side commitment stores. Pragmatic presupposition is thus regarded as an act, consisting in the assertion of a proposition by a utterer different from the speaker, and not resulting directly in the speaker's taking responsibility for it (Ducrot 1984, 190). Instead, this act places a burden of retraction onto the interlocutor, who he has the burden of proving that he cannot accept the dark-side commitment (Ducrot 1969, 35).

\section{Syntactic Defaults: Non-presumptive Polyphonic Articulation}

The analysis of the different voices in an utterance and most importantly the description of presupposition as a point of view representing a generic collective commitment (a collective voice) leads to interpreting all natural utterances as fundamentally involving a plurality of points of view (Nølke 1994b, 154). The speaker interacts with such voices, and associates himself with or refuses commitments that belong to other discourse entities. This approach to presupposition can explain some famous utterances in which the presupposition trigger does not result in a pragmatic presupposition (Abbott 2006).

\subsection{Existential Presuppositions}

The most famous example of existential presupposition is the one characterizing example 4 above:

4. The present king of France is wise.

4 introduces two distinct points of view, one attributed to a collective voice (which will be referred to as $U_{c}$, responsible for what is presupposed, "there is a king of France at present"), and another to the speaker $\left(\mathrm{U}_{1}\right.$, responsible for what is stated, "he is wise"). In this case, the point of view of the speaker and the one of the collective voice coincide (Nølke 1994b); however, it is possible to distinguish the two voices and commitments, such as in the following sentence:

13. The present king of France does not exist (Hintikka 2004, 260)

In this case, the speaker is not committing himself to the existence of any king of France. Rather, he is denying this commitment. He states a contradiction between an entity claimed at the same time to be the king of France at present, and not to exist. This sentence can be analyzed by situating it in context, and bringing to light its polyphonic structure. The speaker refers to (indirectly quotes) an assertion, 
attributed to a different utterer $\left(\mathrm{U}_{2}\right)$, and distinguishes his own commitments from the ones of the utterer. We can represent this polyphonic structure as follows:

13'. ( $\mathrm{I}, \mathrm{U}_{1}$, hold that the individual the $\mathrm{U}_{2}$ refers to as) (")The present king of France(") does not exist.

The speaker (or, according to Ducrot, the voice of the first utterer representing the speaker's point of view) corrects, or rather specifies his own commitments.

This type of analysis can explain the contextual neutralization (Abbott 2006) of the presupposition analyzed by Grice (Grice 1989, 271):

\section{Case 2}

Further, if I am well known to disbelieve in the existence of such a person $<$ The loyalty examiner>, though others are inclined to believe in him, when I find a man who is apprised of my position, but who is worried in case he is summoned, I could try to reassure him by saying, "The loyalty examiner won't summon you, don't worry." Then it would be clear that I said this because I was sure there is no such person.

The distinction between the speaker's and the hearer's points of view can explain the conflicting presumptions underlying the presupposition:

(a) The members of a community should know (be committed to the fact) that the loyalty examiner exists (encyclopedic presumption).

(b) The uniqueness and the existence of the referent of a definite description is presumed to be accepted by the interlocutors (linguistic presumption).

(c) The Hearer should know (be committed to the fact) that the Speaker is committed to the non-existence of the loyalty examiner (encyclopedic, specific presumption).

The Speaker in this case relies on the conflict between the generic encyclopedic presumption and the more specific and less defeasible one. The Speaker can be presumed to hold that the examiner exists based on the fact that he belongs to the community of the Hearer; however, this presumption conflicts with another one, more specific, based on his previous dialogues. The phenomenon of "neutralization" is rather a case of conflicts of presumptions, which is resolved by interpreting nonpresumptively the polyphonic articulation of the utterance. The speaker thus reports the commitment of the common opinion, but distinguishes himself from it. The polyphonic structure can be reconstructed as follows:

(I, $\mathrm{U}_{1}$, hold that the individual the $\mathrm{U}_{2}$ refers to as) (")The loyalty examiner(") won't summon you (as he does not exist).

The difference between case 2 and 12 or 13 above is that the speaker does not explicitly reject the commitment - he does not even need to correct the previous utterance and renegotiate the commitments resulting from it. The presupposition is cancelled by facing the Hearer with a contradiction of presumptions and presumptive conclusions (the Speaker is presumed to be committed to the existence of the examiner based on $a$ ) and $b$ ); the Speaker is presumed not to be committed 
to the existence of the examiner based on $c$ ). This contradiction is resolved by distinguishing the utterers: the presupposition triggered (linguistic presumption) is a commitment of the common opinion (encyclopedic, general presumption) but not of the Speaker (encyclopedic, specific presumption).

\subsection{Factives}

This polyphonic analysis of utterances can also explain the phenomena of presupposition cancellation in cases of hard triggers (Atlas and Levinson 1981, 6), such a factives (Abrusán 2016; Kay 1992, 364). For example, we consider the following statement:

14. John does not regret killing his mother because he did not kill her (Gazdar 1979, 72)

We can analyze (14) by noticing that two voices are clearly distinguished, and a third one (representing the presupposition "John killed his mother") is attributed by a collective voice. The speaker, identified with a first utterer, denies metalinguistically the statement made by a second voice ("John regrets killing his mother") and corrects the commitments resulting from the presupposition thereof. The speaker is refusing to accept the use of "to regret" for describing the condition of John, as it would result in a commitment incompatible with the speaker's ones, explicitly stated ("because he did not kill her"). This implicit dialogue within the utterance can be represented as follows:

14'. (I, $\mathrm{U}_{1}$, maintain that the event $\mathrm{U}_{2}$ described as) (")Johnis sorry because (what $\mathrm{U}_{\mathrm{c}}$ maintains, namely that) "John killed his mother"(") cannot be accepted because he did not kill her.

This statement involves a presupposition nested within the statement made by a voice from which the speaker intends to distinguish himself from. The second utterer deploys the point of view advanced by a collective voice (to which $\mathrm{U}_{2}$ and potentially $\mathrm{U}_{1}$ belong). This commitment could be accepted by $\mathrm{U}_{1}$ just upon acceptance of $\mathrm{U}_{2}$ 's statement. However, $\mathrm{U}_{1}$ refuses this commitment by correcting the description of the state of affairs (John did not "regret killing his mother").

The polyphonic analysis of cancellation of presuppositions triggered by factives can explain also a more complex case, namely ironic cancellation. In this case, the speaker is presumed to hold the presupposition that a second utterer cancels. For example we consider the following excerpt from a newspaper article ${ }^{5}$ :

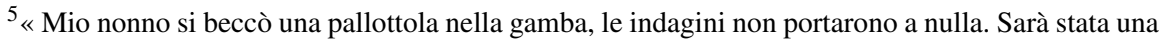
casualità, perché, come tutti sanno: la mafia non esiste » Dina Lauricella, Palermo: le minacce non esistono, è solo Curtigghiu, Il Fatto Quotidiano 1 June 2016 (Retrieved on 1 June 2016).
} 


\section{Case 3}

My grandfather was shot in his leg, the police investigations were unsuccessful. It must have been pure chance, as everyone knows that the Mafia does not exist.

The speaker communicates an utterance whose presupposition (mafia does not exist), triggered by the factive verb "to know," is grounded on the following presumptions:

(a) The members of a community should know (be committed to the fact) that Mafia does not exist (encyclopedic presumption).

(b) The factual truth of the object of a factive verb is presumed to be accepted by the interlocutors (linguistic presumption).

(c) The Hearer should know (be committed to the fact) that the Speaker is committed to the existence of the Mafia (encyclopedic presumption: previous dialogues; context).

(d) The members of a community should know (be committed to the fact) that chance cannot explain a man being shot for taking action against Mafia (encyclopedic presumption).

The Speaker introduces a second utterer $\left(\mathrm{U}_{2}\right)$ who claims that "everyone knows that mafia does not exist." This indirect reported speech introduces the presupposition shared by $U_{2}$ and the collective voice $U_{c}-$ that the Mafia does not exist (case in turn similar to "the king of France does not exist" analyzed at 13 above). However, this presupposition conflicts with what the speaker is presumed to hold based on a specific encyclopedic presumption (the Speaker is an anti-mafia activist) and the presumptions and evidence associated with or drawn from the context (the Mafia usually shoots people taking action against them; the grandfather was fighting the Mafia; chance cannot explain shooting...). The contradiction is resolved by distinguishing the two voices and the common opinion displayed by $\mathrm{U}_{2}$, and showing how it is impossible to hold the speaker committed to $p p$. the utterance can be explained then as follows:

(I, $\mathrm{U}_{1}$, maintain that the event $\mathrm{U}_{2}$ described as) (")It must have been pure chance, aseveryone knows that (what $U_{c}$ maintains, namely that) "the Mafia does not exist"(") (does not make sense).

Case 3 is thus somehow similar to Case 2 above, as the presupposition is cancelled by attributing it to a different utterer and implicitly denied by the speaker. The denial is implicit as it is carried out by means of a contradiction between presumptions. It is the strength of the presumptions leading to the Speaker's commitment to the existence of Mafia compared to the weaknesses of the contrary possibility that leads to a non-presumptive reading of the polyphonic articulation. 


\section{Conclusion}

Pragmatic presupposition is in first place a pragmatic phenomenon, namely it contributes to expressing the speaker's communicative intention (Geurts 1999, 3233). From a dialogical point of view, speaker's intentions can be linked back to their commitments, namely what they accept and hold based on their utterance or previous utterances or rather what they can be considered to be responsible for. This approach to communication can be used to explain the phenomenon of presupposition and presupposition neutralization and cancellation.

Commitments are essentially intertwined with presumptions. Since it is impossible to know what an interlocutor is committed to, the only access to this information is presumptive reasoning, namely drawing conclusions from premises describing the ordinary or normal expectations. Such presumptions can concern linguistic behavior, encyclopedic information, or values and preferences that can be drawn from previous utterances, dialogues, or shared events. The defeasibility conditions depend on the possibility of finding or introducing evidence leading to a default of the presumption. Clearly, the more specific or stronger the presumption, the stronger the conclusion. On the one hand, the speaker acts based on various types of presumptions to predict the speaker's acceptance of certain implicit commitments. On the other hand, the hearer uses presumptive reasoning to interpret the speaker's intention.

Presupposition can be analyzed from a dialogical point of view as an act aimed at modifying the interlocutors' commitments. Presupposition can presumptively be used to remind the interlocutors of an implicit commitment, thus bringing to the light side tacit or dark-side commitments. However, it can be also used to impose onto the interlocutor a commitment, namely inserting a commitment into the hearer's commitment store without taking responsibility for it. Presupposition can thus be used for different acts, and can differently affect the dialogical situation. Prototypically (in ordinary and common conditions), presuppositions are used as reminders. However, when the hearer cannot be presumed to hold such an implicit commitment, the act needs to be interpreted non-presumptively as a directive, a performative, or an assertive.

The cancellation (and in some case the neutralization) of presuppositions can be explained from a dialogical (commitment-based) perspective as a non-presumptive interpretation of the utterance triggered by a conflict of presumptions. In such cases, the speaker presumes at the same time that a proposition is accepted (or acceptable) and not accepted (or acceptable). This conflict can lead to reinterpreting the semantic or syntactic structure of the utterance. From a semantic point of view, lexical items can be reinterpreted so that the presupposed content does not conflict with the stronger mutual or encyclopedic presumptions. From a syntactic point of view, the polyphonic articulation of the utterance is reinterpreted, and the speaker either explicitly or implicitly refuses the commitments apparently attributed to him by a second utterer or common voice. In this fashion, he corrects or brings to light the implicit commitments of the interlocutors. 
Acknowledgements This work was supported by the Fundação para a Ciência e a Tecnologia (research grants no. IF/00945/2013, SFRH/BPD/115073/2016, PTDC/FER?FIL/28278/2017, and PTDC/MHC-FIL/0521/2014)

\section{References}

Abbott, Barbara. 2006. "Where Have Some of the Presuppositions Gone?" In Drawing the Boundaries of Meaning: Neo-Gricean Studies in Pragmatics and Semantics in Honor of Laurence R. Horn, edited by Betty Birner and Gregory Ward, 1-20. Amsterdam: John Benjamins Publishing.

Abrusán, Márta. 2016. "Presupposition Cancellation: Explaining the Soft-Hard Trigger Distinction." Natural Language Semantics 24 (2): 165-202.

Allan, Keith. 2013. "What Is Common Ground?" In Perspectives in Pragmatics, Philosophy \& Psychology Volume 2, edited by Alessandro Capone, Franco Lo Piparo, and Marco Carapezza, 285-310. Cham: Springer. doi:https://doi.org/10.1007/978-3-319-01014-4_11.

Asher, Nicholas, and Alex Lascarides. 1998. "The Semantics and Pragmatics of Presupposition." Journal of Semantics 15 (3): 239-300. doi:https://doi.org/10.1093/jos/15.3.239.

Atlas, Jay David. 2005. Logic, Meaning, and Conversation. Oxford: Oxford University Press. doi:https://doi.org/10.1093/acprof:oso/9780195133004.001.0001.

2008. "Presupposition." In The Handbook of Pragmatics, edited by Laurence Horn and Gregory Ward, 29-52. Oxford: Blackwell Publishing Ltd. doi:https://doi.org/10.1002/9780470756959.ch2.

Atlas, Jay David, and Stephen Levinson. 1981. "It-Clefts, Informativeness and Logical Form: Radical Pragmatics (Revised Standard Version).” In Radical Pragmatics, edited by Peter Cole, 1-62. New York: Academic Press.

Bakhtin, Mikhail Mikhailovich. 1981. The Dialogic Imagination. Austin: University of Texas Press.

1986. Speech Genres and Other Late Essays. Austin: University of Texas Press.

Beaver, David. 2010. "Have You Noticed That Your Belly Button Lint Colour Is Related to the Colour of Your Clothing." In Presuppositions and Discourse: Essays Offered to Hans Kamp, edited by Rainer Bäuerle, Uwe Reyle, and Thomas Zimmerman, 65-99. Oxford: Elsevier.

Beyssade, Claire, and Jean-Marie Marandin. 2006. "The Speech Act Assignment Problem Revisited: Disentangling Speaker's Commitment from Speaker's Call on Addressee.” In Empirical Issues in Syntax and Semantics, edited by Olivier Bonami and Patricia Cabredo Hofherr, 6:3768. Paris: Presses Universitaires de Paris Sorbonne.

2009. "Commitment: Une Attitude Dialogique." Langue Française, no. 2. Armand Colin/Dunod: 89-107. http://www.cairn.info/revue-langue-francaise-2009-2-page-89.htm.

Capone, Alessandro. 2005. "Pragmemes (a Study with Reference to English and Italian)". Journal of Pragmatics 37 (9): 1355-71. doi:https://doi.org/10.1016/j.pragma.2005.01.013.

. 2010. "On the Social Practice of Indirect Reports (Further Advances in the Theory of Pragmemes)." Journal of Pragmatics 42 (2): 377-91. doi:https://doi.org/10.1016/j.pragma.2009.06.013.

2016. The Pragmatics of Indirect Reports: Socio-Philosophical Considerations. Cham: Springer.

. 2017. "Shifts of Footing in Mrs. Hillary Clinton's Emectoral Speech." RASK.

Clark, Herbert H., and Richard J. Gerrig. 1990. "Quotations as Demonstrations." Language 66 (4): 764-805.

Ducrot, Oswald. 1966. “'Le Roi de France Est Sage'. Implication Logique et Présupposition Linguistique." Etudes de Linguistique Appliquée 4: 39-47.

. 1968. "Le Structuralisme en Linguistique.” In Qu'est-Ce Que le Structuralisme?, edited by Oswald Ducrot and Tzvetan Todorov, 13-96. Paris: Seuil.

. 1969. "Présupposés et Sous-Entendus." Langue Française, no. 4: 30-43. . 1972a. "De Saussure à la Philosophie du Langage." In Les Actes de Langage, 7-34. Paris: Hermann. 
1972b. Dire et ne pas Dire. Paris: Hermann.

1980. Les Mots du Discours. Paris: Minuit.

1982. "La Notion de Sujet Parlant." Recherches sur la Philosophie et le Langage 2. Université de Grenoble: 65-93.

1984. Le Dire et Le Dit. Paris: Minuit.

Fløttum, Kjersti. 2010. "EU Discourse: Polyphony and Unclearness." Journal of Pragmatics 42 (4). Elsevier: 990-99.

Gazdar, Gerald. 1979. "A Solution to the Projection Problem." In Syntax and Semantics. Vol. 11: Presupposition, edited by Choon-Kyu Oh and David Dinneen, 1:57-89. New York: Academic Press.

. 1981. "Speech Act Assignment." In Elements of Discourse Understanding, edited by Aravind Joshi, Bonnie Webber, and Ivan Sag, 64-83. Cambridge: Cambridge University Press.

Geurts, Bart. 1999. Presuppositions and Pronouns. Oxford: Elsevier.

2017. "Presupposition and Givenness." In Oxford Handbook of Pragmatics, edited by Yan Huang, 180-98. Oxford: Oxford University Press.

Grice, Paul. 1989. Studies in the Way of Words. Cambridge: Harvard University Press.

Hamblin, Charles Leonard. 1970. Fallacies. London: Methuen.

Hare, Richard. 1970. "Meaning and Speech Acts." The Philosophical Review 79 (1): 3-24.

Hintikka, Jaakko. 2004. "Logic of Conversation as a Logic of Dialogue." In Philosophical Grounds of Rationality, edited by Richard Grandy and Richard Warner, 259-76. Oxford: Clarendon Press.

Hobbs, Jerry R. 1979. "Coherence and Coreference." Cognitive Science 3: 67-90. doi:https://doi.org/10.1207/s15516709cog0301_4.

Horn, Laurence. 1985. "Metalinguistic Negation and Pragmatic Ambiguity." Language 61: 121174.

Huang, Yan. 2014. Pragmatics. Oxford: Oxford University Press.

Kay, Paul. 1992. "The Inheritance of Presuppositions." Linguistics and Philosophy 15 (4). Springer: 333-79.

Kempson, Ruth. 1975. Presupposition and the Delimitation of Semantics. Cambridge: Cambridge University Press.

Levinson, Stephen. 2000. Presumptive Meanings: The Theory of Generalized Conversational Implicature. Cambridge, Mass.: MIT Press.

Lewis, David. 1979. "Scorekeeping in a Language Game." Journal of Philosophical Logic 8 (1): 339-59. doi:https://doi.org/10.1007/BF00258436.

Macagno, Fabrizio. 2018. "A dialectical approach to presupposition." Intercultural Pragmatics 15(2). 291-313. doi:https://doi.org/10.1515/ip-2018-0008.

Macagno, Fabrizio. 2015. "Presupposition as Argumentative Reasoning." In Interdisciplinary Studies in Pragmatics, Culture and Society, edited by Alessandro Capone and Jacob Mey, 465 87. Cham: Springer. doi:https://doi.org/10.1007/978-3-319-12616-6_18.

Macagno, Fabrizio, and Alessandro Capone. 2016a. "Presuppositions as Cancellable Inferences." In Pragmemes and Theories of Language Use, edited by Keith Allan, Alessandro Capone, and Istvan Kecskes, 45-68. Cham: Springer.

—. 2016b. "Uncommon Ground." Intercultural Pragmatics 13 (2): 151-180. doi:https://doi.org/10.1515/ip-2016-0007.

Macagno, Fabrizio, and Giovanni Damele. 2013. "The Dialogical Force of Implicit Premises: Presumptions in Enthymemes." Informal Logic 33 (3): 361-89. http://windsor.scholarsportal.info/ ojs/leddy/index.php/informal_logic/article/view/3679/3138.

Macagno, Fabrizio, and Douglas Walton. 2014. Emotive Language in Argumentation. Cambridge: Cambridge University Press. doi:https://doi.org/10.1017/CBO9781139565776.

Mackenzie, Jim, and Phil Staines. 1999. "Hamblin's Case for Commitment: A Reply to Johnson." Philosophy \& Rhetoric 32 (1): 14-39.

Nølke, Henning. 1994a. "La Dilution Linguistique Des Responsabilités: Essai de Description Polyphonique Des Marqueurs Évidentiels“ il Semble Que et Il Paraît Que.’" Langue Française, 84-94. 
1994b. Linguistique Modulaire: De La Forme Au Sens. Vol. 28. Louvain and Paris: Peeters Publishers.

Recanati, François. 2000. Oratio Obliqua, Oratio Recta. Cambridge, Mass.: MIT Press.

_. 2010. Truth-Conditional Pragmatics. Oxford: Oxford University Press.

2016. "Force Cancellation." Draft.

Reimer, Marga, and Anne Bezuidenhout, eds. 2004. Descriptions and Beyond. Oxford: Oxford University Press.

Rescher, Nicholas. 2006. Presumption and the Practices of Tentative Cognition. Cambridge: Cambridge University Press. doi:https://doi.org/10.1017/CBO9780511498848.

Searle, John. 1969. Speech Acts: An Essay in the Philosophy of Language. Cambridge: Cambridge University Press.

Searle, John, and Daniel Vanderveken. 2005. "Speech Acts and Illocutionary Logic." In Logic, Thought and Action, 109-32. Dordrecht: Springer Netherlands.

Simons, Mandy. 2003. "Presupposition and Accommodation: Understanding the Stalnakerian Picture." Philosophical Studies 112 (3): 251-78.

. 2013. "On the Conversational Basis of Some Presuppositions." In Perspectives on Linguistic Pragmatics, Perspectives in Pragmatics, Philosophy \& Psychology 2, edited by Alessandro Capone, Franco Lo Piparo, and Marco Carapezza, 329-48. Cham: Springer.

Soames, Scott. 1982. "How Presuppositions Are Inherited: A Solution to the Projection Problem." Linguistic Inquiry 13 (3): 483-545.

2002. Beyond Rigidity: The Unfinished Semantic Agenda of Naming and Necessity. Oxford: Oxford University Press.

Stalnaker, Robert. 1973. "Presuppositions." Journal of Philosophical Logic 2 (4): 447-57. doi:https://doi.org/10.1007/bf00262951.

. 1974. "Pragmatic Presuppositions." In Semantics and Philosophy, edited by Milton Munitz and Peter Unger, 197-214. New York: New York University Press. doi:https://doi.org/10.1093/0198237073.003.0003.

1984. Inquiry. Cambridge, Mass.: MIT Press.

1998. “On the Representation of Context." Journal of Logic, Language and Information 7 (1): 3-19. doi:https://doi.org/10.1023/A:1008254815298.

2002. "Common Ground." Linguistics and Philosophy 25: 701-21. doi:https://doi.org/10.1023/A:1020867916902.

Strawson, Peter. 1950. "On Referring." Mind 59 (235): 320-44.

_ 1954. "A Reply to Mr. Sellars." The Philosophical Review 63 (2): 216-31. 118.

1964b. "Intention and Convention in Speech Acts." The Philosophical Review 73 (4): 439-60. . 1971. "Identifying Reference and Truth-Values." In Logico-Linguistic Papers, 75-95. London: Methuen.

Voloshinov, Valentin Nikólaievich. 1986. Marxism and the Philosophy of Language. Cambridge, Mass., Mass.: Harvard University Press.

von Fintel, Kai. 2008. "What Is Presupposition Accommodation, Again?" Philosophical Perspectives 22 (1): 137-70. doi:https://doi.org/10.1111/j.1520-8583.2008.00144.x.

Von Fintel, Kai. 2004. "Would You Believe It? The King of France Is Back! (Presuppositions and Truth-Value Intuitions)." In Descriptions and Beyond, edited by Marga Reimer and Anne Bezuidenhout, 315-41. Oxford: Oxford University Press.

Walton, Douglas. 1985. Arguer's Position. Westport: Greenwood Press. 1987. Informal Fallacies. Amsterdam: John Benjamins Publishing.

1995. Argumentation Schemes for Presumptive Reasoning. Mahwah: Routledge. doi:https://doi.org/10.4324/9780203811160.

Walton, Douglas, and Erik Krabbe. 1995. Commitment in Dialogue. Albany: State University of New York Press.

Walton, Douglas, Christopher Reed, and Fabrizio Macagno. 2008. Argumentation Schemes. New York: Cambridge University Press. doi:https://doi.org/10.1017/CBO9780511802034. 